\title{
Estudo Histopatológico e Viabilidade de Análises do DNA em Ossadas Humanas Expostas a Condições Tafonômicas: aplicações na identificação forense
}

\author{
Histopathological Study and Feasibility of DNA Analysis in Human \\ Bones Exposed to Taphonomic Conditions: applications in Forensic \\ Identification
}

\author{
Mirella Perruccio Soler
}

Orientadora: Prof ${ }^{-}$Dr ${ }^{a}$ Edna Sadayo Miazato Iwamura. Co - orientadora: Prof ${ }^{-}$Dr ${ }^{a}$ Maria Teresa de Seixas Alves

Soler MP. Estudo Histopatológico e Viabilidade de Análises do DNA em Ossadas Humanas Expostas a Condições Tafonômicas: aplicações na identificação forense. São Paulo, 2012. 192f. Tese (Mestrado). Universidade Federal de São Paulo. Escola Paulista de Medicina. Programa de Pós-graduação em Patologia. Saúde, Ética \& Justiça. 2012;17(1):43.

\begin{abstract}
RESUMO: Brasil apresenta a 6 a $^{\mathbf{a}}$ maior taxa de homicídios do mundo e são muitos os casos em que ossos humanos post-mortem que estiveram expostos a condições tafonômicas variadas são os únicos materiais disponíveis para a identificação. Fatores ambientais e o tempo podem exercer influência direta sobre o tecido ósseo e suas células, dificultando a viabilidade da análise do DNA para identificação humana. Os objetivos do trabalho são: avaliar alterações microscópicas no tecido ósseo, verificar a presença de células típicas e correlacionar os achados entre si e com a quantidade de DNA e amplificação de marcadores genéticos. Foram utilizados fragmentos córtico-medulares de diáfise femoral de 20 cadáveres esqueletizados encontrados no período de 1998 a 2009 na Microrregião de Ribeirão Preto. Para a análise histopatológica, cortes histológicos foram corados por H\&E, Prata Metenamina e Ácido Periódico de Schiff, e imunomarcados por CD31 e CD34. Na análise do DNA, os fragmentos foram desgastados e pulverizados, empregando-se 3 métodologias de extração: colunas de sílica, solvente orgânico e desmineralização completa. Os marcadores genéticos foram amplificados por kit de STR e de mini-STR. Observaram-se osteócitos em todos os casos variando de 1 a 40, não houve expressão dos marcadores de célula endotelial e foi constatada a presença acentuada de fungos em $35 \%$ dos casos. As variáveis correlacionadas com maior quantidade de DNA e de alelos amplificados foram: maior área óssea, maior número de núcleos e menor presença de fungos. O sucesso na obtenção do perfil genético completo de $50 \%$ das amostras foi alcançado através da extração de DNA pelo método de desmineralização e da amplificação por kit de mini-STR. Melhores resultados moleculares a partir de ossos esqueletizados em clima tropical podem ser obtidos pela qualificação macro e microscópica da amostra, extração de DNA através de desmineralização e utilização de primers que amplificam regiões do DNA mais curtas.
\end{abstract}

DESCRITORES: Patologia Legal; DNA; Antropologia Forense; Ossos.

Soler MP. Histopathological Study and Feasibility of DNA Analysis in Human Bones Exposed to Taphonomic Conditions: applications in Forensic Identification. São Paulo, 2012. 192f. Tese (Mestrado). Universidade Federal de São Paulo. Escola Paulista de Medicina. Programa de Pós-graduação em Patologia. Saúde, Ética \& Justiça. 2012;17(1):43.

ABSTRACTS: Brazil has the 6th highest homicide rate in the world and there are many cases in which post-mortem human bones that were exposed to diverse taphonomic conditions are the only materials available for identification. Environmental factors and time can exert direct influence on bone tissue and its cells and on the DNA analysis feasibility for human identification. Objectives of this study were: evaluate bone microstructure, verify typical cells presence and correlate these findings with DNA amount and genetic markers amplification. Cortico-medullary fragments of femoral diaphysis were used from 20 skeletonized corpses found in 1998-2009 in Ribeirao Preto micro-region. For histopathological analysis, sections were stained with $\mathrm{H}$ \& $\mathrm{E}$, methenamine silver and Periodic Acid-Schiff, and immunostained with CD31 and CD34 markers. For DNA analysis, the fragments were sanded, pulverized and three extraction methodologies were used: silica columns, organic solvent and complete demineralization. Genetic markers were amplified by STR and miniSTR kits. Osteocytes were found in all cases ranging from 1 to 40; there was no expression of endothelial cell markers and fungus presence was observed in all cases. Variables correlated with higher DNA amounts and amplified alleles were: larger bone area, higher nuclei number and fungus quantity. Success in obtaining complete genetic profile from $50 \%$ of the samples was achieved through DNA extraction by demineralization method and mini-STR kit amplification. This study demonstrates the importance of extraction methods and removal of DNA bounded in the mineralized matrix, besides the use of primers that amplify small DNA fragments in bones skeletonized in tropical climate. 